\title{
ANTHROPOLOGICAL PERSPECTIVES ON FOLKLORE: UNDERPINNINGS ON SOME NEPALI FOLKLORE
}

\author{
Prakash Upadhyay*
}

\begin{abstract}
The main objectives of this article is to explore how people use folklore for interaction, and how folklore is useful for managing social/cultural situations for identity making. Pedestal on qualitative secondary data were obtained from various literature, books, journals and articles. The conceptual frame of the study respite on four field approaches of anthropology which comprehend folklore at local, regional, national, and global scales and are supportive in reflecting the understandings in application and seeking ways to adjust with communities to assist them in preserving folklore or in bridging the knowledge-community dissection--understanding and analyzing ethnic behaviors, their identity and institutions, human-culture-nature relation, micro-macro structural relations. With a unique cultural heritage, Nepal is copious with diverse folklore based on legends, religion, popular beliefs etc. They are the traditions of ethnic cultures, subcultures, or groups to express feelings. Nepali folklore establishes relationship of local people with their culture, ethno-cognition, using folklore for interaction and unity, for managing social/cultural/ ecological situations in various institutional settings for identity making, explaining the natives as possessing an exclusive system of perceiving and organizing phenomenon. Anthropology's in-depth fieldwork methodology, long rendezvous in questions of society-culture interactions and broad holistic view yields precious insights into Nepali folklore.
\end{abstract}

Key Words: holistic, genres, netography, sorcery, bizarre, grounded, agency.

\section{INTRODUCTION}

As a complex discipline anthropology has manifold approaches and divisions. Anthropology is often defined as being holistic and is known as a discipline with four fields based on a four-field approaches that sees anthropology composed of four subfields: Biological or Physical anthropology, Social and Cultural anthropology, Linguistic and Archeological anthropology. This approach is conventionally understood as developed by Franz Boas who promoted the discipline of anthropology in the United States (Anderson 2003, Alice et al., 1998). However, a

Dr. Upadhyay is Reader in Anthropology at Prithvi Narayan Campus, Department of Sociology/Anthropology, T.U., Pokhara, Nepal 
recent re-assessment of the evidence has indicated that the idea of fourfield anthropology has a more complex 19th-century history in Europe and North America (Hicks, 2013). The four field approach of anthropology was motivated by holistic approach to the study of human behavior which included integrated analytical attention to culture history, material culture, anatomy and population history, customs and social organization, folklore, grammar and language use. With the increasing professionalization and specialization of separate disciplines, linguistics and archaeology came to be regarded largely as separate disciplines. And today, physical anthropologists often collaborate closer with biology and medicine than with cultural anthropology (Borofsky, 2002). Of the four fields or branches, cultural anthropology, which is also referred to as social anthropology, ethnology or ethnography, is most closely associated with folklore. Folklore is a facet of cultural milieu on which Anthropological lens throws harsh light but with soft focus.Based on graphic metaphors of harsh light and soft focus, anthropological worldview of harsh light denotes a concern for basic reality of folklore embedded with Nepali conditions in various settings, soft focus attempts to grapple all facets of that stipulation and the roles folklores play in integrating cultures and societies.

An important place for anthropological studies, Nepal historically mistreated as a guinea pig by Westerners, is known as a country with a distinctive and strong cultural heritage. It is therefore little wonder that Nepal's folklore plays a large role in society for identity making of the folk (people). In Nepal there are different folklore based on legends, music, oral history, proverbs, jokes, popular beliefs, fairy tales, stories, tall tales, and customs that are the traditions of a culture, subculture, or group to express grief, happiness etc. that depict the identity of people. It is also the set of practices through which expressive genres are shared.

Folklore belief systems have also a substantial effect on human attitudes (inc. ecological) and can hence play a key role in ecological conservation practices. Gazing into the belief systems is instrumental in ascertaining the collective unconscious of a group, that is, the underlying values of a culture: ambitions, their uncertainties, fears, motivations and morals. They represent collective and inherited patterns of thought in the form of folklore. Folklore research topic was selected in this article because of its spiritual, political and historical reaches in Nepali society. Folklore, mythology and storytelling articulate to spiritual concepts and values, but they also encompass ideas on contemporary Nepali history and localized environments, something that religious texts alone do not; folklore best exemplifies the shared unconscious of both dominator cultures and partnership cultures hence making folklore study crucial. 


\section{OBJECTIVES}

The key objectives of this article are to explore key anthropological concerns that include (a) how do people use folklore for interaction, and to what effect? (b) how is folklore useful for managing social/cultural situations, in various institutional settings?, (c) what are the major folklore of Nepal? and (d) how are they institutionally organized for identity making?

\section{METHODS}

This article is based on secondary data and they are qualitative in nature. Data were obtained from various literatures that include books, journals, booklets, articles, websites etc. The conceptual frame of the study respite on four field approaches of anthropology embedded with folklore research methods. It exemplifies folklore as an artistic communication in small groups and folklore relations with anthropology for managing social and cultural situations.

\section{RESULTS}

Folklore is that art or form of interaction, comprising an assortment of stories, sayings, proverbs, spells, songs, incantations, and other formulas, which employs spoken language as its medium. In Nepali society it includes fairy tales, myths, and legends, superstitions, festival rites, traditional games, folk songs, popular sayings, arts, crafts, folk dances, and the like. It is very much an organic phenomenon underlying many definitions; a body of knowledge, a mode of thought, or a kind of art. Since 1960's, folklore has been defined as artistic communication in small groups (Ben-Amos, 1972), meaning folklorists focus upon the relationship of individual creativity to the collective order. Folklorists are equally concerned with aesthetic and expressive aspects of culture and the people and societies that make and respond to creative acts. The major shift in folkloristic is a move from collection and categorization to a new focus on synthesis recognizing the interactions between how an individual tells a story and how the audiences react and interact, interrelationships between art, architecture and other expressive elements of culture. Folklorists look at the dynamic relations between the socially given, the traditional, and the creative individual. The field has re-calibrated itself from a focus on the traditional and ready-made, to a focus on the balance of traditional and emergent, socially given and creative. Such synthetic work seeks to better understand the world by recognizing the circular system of individual, group, and expression. Folklorists nowadays have and use theories, but they also strive to maintain an empirical richness in their study, letting the fieldwork, the data, and the people involved direct the big picture as much as possible. For anthropologists, as traditional tales, folkloreis oral stories and legends embedded with local cultural 
realities, transmitted from person to person via an apt interaction. In Nepali societies there are fantastic legends, taken to be real with no author and are shared across regions with a hidden moral lesson that was being taught, warning the gullible of the dangers that lurked. They define cultures past and present viable though interaction in small groups across different caste/ethnicities.

Oral history dole out as a useful evidence as to how anthropology and folklore can reconcile their differences and work productively together in managing social/cultural situations in various institutional settings and studying what it means to be human. Folklore tradition in Nepal hub on the relationship between traditionality and modernity in contemporary research and social life, the historical emergence of traditional cultural forms, and the importance of tradition in shaping along with managing political and social/cultural situations in various institutional settings and social projects. The aim of folklore studies in anthropology is to familiarize people with forms of immaterial folk culture and oral tradition, and to guide them in the central analytic viewpoints and methods of anthropological research. However, the study of folklore in anthropology has changed over time. In the past scholars believed that the subjects (texts or culture) were decaying or disappearing but now anthropologists consider folklore and culture as effective and meaningful processes within the present reality. Fieldwork connects folklorists to the community and provides contextual knowledge for textual analysis. The contribution that anthropology can make to the study of Nepali folklore is to show up the social/cultural nature of folklore. It exists in a social context, it is performed in social contexts and it is understood because it is found in larger social and cultural narratives.

Also, anthropology highlights the necessity to seek out the ways in which past folklore melds into contemporary folk beliefs and tales and should acknowledge that folklore was never static. There was diffusion and there was innovation. Where anthropologists can also provide guidance is in highlighting the futility of seeking purity in folklore past and present. In the present modern societies, folklore exists in interaction with television and other forms of media, and communities will be formed not only by face-to-face storytelling, but also in the sharing of tales via email and the internet. In this context, anthropology and folklore studies could find common grounds in applying the methods and theory of both disciplines to the study of contemporary culture and folklore past and present. The new folklore will, thus, be one a combination of ethnography and netography (Maria et al., 2012). It will be ethnography because it is conducted in both live and online communities. Though new folklore is still being created and distributed, old folklore need not be discarded. A 
study of the folklore collected in the past can shed light on current communities and present cultural practices. In the context of rapidly urbanizing context of Nepal, one should not underrate the continued vitality of folk beliefs prevailing here in remote areas that are useful for managing social, cultural and ecological situations in various institutional settings. There are folk beliefs tied to different aspects of social life, for interaction and for artistic communication in small groups. Nepalese folklore hunts for beliefs and folk knowledge of the past, but there have been no attempts to tie it to the present modern Nepali society and social/cultural situations in various institutional settings. Anthropology describes communities in ethnographies that were in the unchanging present, while folklorists seek to document as tactic past. It would be common benefit to tie past and present together using critical analysis to better comprehend prevailing Nepali traditions, a means of fleshing out our understanding of Nepali history and culture.

Malinowski (1923) observes that an utterance in a primitive language is totally incomprehensible unless it is placed into its cultural setting and related to the circumstances in which it occurs. He argues that folklore can provide us with the context we need to interpret the language or speech of a community that no more exists in its primitive or previous form but is manifested in its customs and traditions. By bridging folklore and anthropology, media and oral traditions, we can provide new venues to understand Nepali folk culture, old and new, as well as expanding our understanding of Nepali history. But in an age of high technology and global capitalism there may be the demise of conventional Nepali cultures making it crucial to act at right time to conserve our folk traditions and to carry out broad anthropological researches.

\section{DISCUSSION}

Nepali folklore and mythology provides readers and listeners with extensive insight into the lives and identities of various ethnic groups. Folklore traditions in Nepal depict the identity of different groups. Such folktales reveal much about ethnic and religious tradition, activities, emotion, superstitions, customs and inhibitions deeply embedded with anthropology and its interpretive tradition. An array of lore that includes anything from spirits, occult practices (witchcraft, magic, and sorcery), ghosts, monsters, urban myths, old wives tales and luck charms are the parts of Nepali rural and urban life. Fisher (1989) argues that understanding spirit possession as a phenomenon necessarily entails understanding the context in which it is spoken of or told about spirits, as much as people, inhabit the hills of Nepal. One cannot linger long in Nepal without becoming aware of the complex interactions among manifold varieties of spirits and humans, attested to through numerous 
offerings, possessions, and cures, and repeatedly re-interpreted through frequently retold tales of possessions. Anthropologists take selected major superstitions, legends, and folklore and discuss their origins, their stories as they are told in the country, and associated traditions. It also includes proverbs and sayings unique to the culture. It helps in finding out how superstitious Nepalese people are and learn about their taboos and fears, both old and modern alike anything from good and bad luck charms and actions. Nepali folklore and stories are typically based upon reality and religious belief, with narration on gods, demons, ghosts, animals, love, and war and so on. Cross-cultural or comparative approach keep away from comparing human nature by not taking belief or style of behavior of managing life for granted in current, studying other cultures with very dissimilar understandings of world. Even a single folktale within Nepal has several variations from region to region. Nepalese folklore has been often recreated through music and dance, particularly by the Newar people who act out stories about gods and heroes through masked dances. There are forests, rivers, valleys, planetary system etc. dotted with legendary myths of their own. Myth in Nepal amounts to a lively legend which manifests itself in the folklore of its diversified ethnic communities. There is different bizarre myths embedded folklore in Nepal that shows the particular identities of different ethnic and caste groups' e.g. (a) Newari folklore from Kathmandu on Khyahs. (b) Hindu Folklore on why the stone Shaligram (Ammonite fossils), Tulasi (Basil Plant) and the Pipal (Banyan Tree) are sacred? (c) Folklore of Yeti the mysterious creature of mountain. (d) Hindu folklore on why lord Ganesh is elephant headed? (e) Folklore on why Seti River flow partly underground at Pokhara, and how did Kali make deepest gorge? (f) Nepali King who believed that he was immortal (g) Himalayan myth on Snow Leopards.

\section{NEWARI FOLKLORE FROM KATHMANDU ON 'KHYAHS'}

Khyahs are to Newari folklore what trolls and elves are to the European heritage. According to Newari folklore Khyahs is a short man-like creature, about two feet tall and furry in a big way - either black or white - and mostly active at night. It's a friendly creature but a shy one. Khyahs attend to Laxmi, the goddess of wealth, and pictures of the deity show them guarding overflowing bags of coins. They move about in forests and villages by secretly- shy as they are - and stay hidden most of the time. But sometimes they might approach people: they can hide in a heartbeat but they can also appear out of nowhere. So we might be lucky to see one - or unlucky, depending on what colour it has. If we encounter a black Khyahs, better close eyes. See a white one, on the other hand, and we are in luck, well - and seeing one brings good luck and happiness. Household Khyahs usually dwell in 
the attic and dark storerooms. They are said to fear electric lighting. The antithesis of the Khyah is the Kawancha, a skeleton. Khyahs and Kawanchas appear as supporting characters in sacred dance dramas of the Newar. Images of Khyahs and Kawanchas are also placed at temples as guardians of the shrine. Elderly people in Kathmandu who claim of seeing Khyahs allege that the closest encounter is a quiet, hairy fellow who came and sat on their laps! Many of those who've seen a Khyahs tell how these Khyahs would come and sit on the edge of their bed for a while, keeping them amazed. Old people who grew up in the heart of Khyahs territory usually tell a simpler reason: Khyahs are shy creatures and so, since Kathmandu has become crowded, urbanized and noisy, many Khyahs left.

HINDU FOLKLORE ON WHY THE STONE SHALIGRAM (AMMONITE fossils), tulasi (Basil Plant) and Pipal (Banyan Tree) are SACRED?

The folktale goes to the earliest times of Britasura who was a very powerful demon. He ruled people ruthlessly and killed many common people. Even the most powerful gods including Lord Shiva were no match for him when it came to fighting. Britasura was to be killed at any cost but he would not die as long as the chastity of his wife, Brinda, remained intact. Lord Vishnu in the disguise of the demon Britasura succeeded in violating Brinda's chastity and the demon was killed in the subsequent encounter. The enraged Brinda cursed Vishnu so that he turned into a stone, plant and tree. These three-stone (Shaligram), plant (Tulasi) and tree (Pipal) are regarded as some of his holy incarnations and are worshipped even to this day by the Hindus.

\section{FolkLORE OF Yeti THE MYSTERIOUS CREATURE OF MOUNTAIN}

A world renowned figure in Nepal's folklore is the legendary abominable Snowman also known as the Yeti which is said to live in the Himalayas and is similar to North America's Bigfoot or Sasquatch. Several reports of sightings of the Yeti have been made in Nepal as well as in China, Siberia and other Asian countries. The Yeti or monstrous Snowman is described as a large apelike creature that uses sound, whistles and cries to communicate. Various individuals have attempted to find out if there is any truth in the stories. They have carefully considered Nepal's folklore as well as making efforts to gather casts of footprints, even going so far as to create devices to capture the mysterious Yeti. Even the famous Sir Edmund Hillary from New Zealand set about probing reports such as one made by Tensing Norgay regarding the Yeti. Despite all these efforts no tangible evidence has been found that confirms the existence of an Abominable Snowman the Yeti. Thus, the Yeti remains an element of Nepalese folklore. 


\section{HINDU FOLKLORE ON WHY GANESH IS ELEPHANT HEADED?}

As the remover of all sorts of obstacles, Ganesh the elephantheaded Hindu god is in the forefront of all worship in Hindu Pantheon. No ritual is undertaken without worshipping him first. This is what the myth has to say about his strange looking human body. It says that Parvati, the wife of Shiva, was in some kind of trouble with her over- romantic or jealous husband Shiva, who always needed to know too much. Her friends advised her to employ her own bodyguard who would safeguard her privacy. So she collected some bukuwa (a kind of paste) to wash her body and from this she molded a child named Som and gave life to him. One day she asked him to guard her door and not to allow anybody in while she took a bathe, but Shiva returned home and wishing to enter her room was prevented. Shiva became angry, and not knowing who the child was, decapitated him. Parvati came out and cried at the fate of her Som, while Shiva trying to pacify her ordered his servants to find any creature, chop the head and bring it to him. They found a white elephant, chopped its head off, and brought it to Shiva, who added the head to the torso of Ganesh and provided life to him.

FOLKLORE ON WHY DOES THE SETI RIVER FLOW PARTIALLY UNDERGROUND AT POKHARA?

According to folklore, Seti the white river and Kali the black river, that flow from Jomsom are sisters born to Himalaya. Once they had a bet as to which of them would make it first to the ocean. In their wild, adventurous journey to the big sea, they ran an amazing race. Their shooting down from the Himalaya, their falling from the cliffs as waterfalls, the breaking down of rocks, the knocking off of mountains, hills and highlands that stood in their way, was an incredible sight to behold. Upon reaching Pokhara Seti saw an old woman ploughing her field and another working on the slanting roof of a village house. She felt sorry for these women and went under- ground to avoid any such encounters. Kali, on the other hand, came across a different situation in the course of the journey. There were male porters in bare feet carrying heavy loads on their backs on narrow mountain trails, to support their families. Kali too decided to hide her- self by digging the deepest gorge on earth. Both Seti and Kali during their journey joined a number of big rivers. When they reached their destination they had learnt a lot about human suffering so they both decided to flow partially underground at Pokhara so that not to disturb the people.

\section{THE NEPALI KING WHO BELIEVED THAT HE WAS IMMORTAL}

There was once a philosopher king in Patan state of Kathmandu, who believed that he was immortal. So, to convince people about his 
belief he installed a statue of himself in front of his palace. The statue had a Naga (snake god) forming a canopy over his head and a bird on top of the Naga's head, which looked as if it was about to fly. The statue was devoted in prayer to Taleju, the goddess of Patan state of Kathmandu. Then the king proclaimed that as long as the bird perched on top of the Naga, his subjects should know that he was still alive. One day the king disappeared mysteriously. The statue prayed to Taleju and the bird had not flown away. Thus, once a year there is a big festival at which the golden window of his palace is left open in the hope of his return. A dish of meal is also served for him regularly.

\section{HIMALAYAN MYTH ON SNOW LEOPARDS IN NEPAL HIMALAYAS}

Snow leopard conservation has been an issue of challenge for anthropologists of Nepal as it one of the endangered species. The snow leopard, which lives in the Glaciers of the Himalaya, is a mythical creature of the Buddhist realm. In Nepal Himalayas many indigenous beliefs and shamanistic practices, reflecting local pre-Buddhist traditions, were incorporated and subsequently reworked into the Buddhist pantheon and ritual system. One such ritual in Manang connected to the snow leopard and its depredation forbids alpine herders to roast meat, for otherwise the mountain god will send its $d o g$, (i.e. snow leopard) and one has to suffer livestock losses. In Dolpo there are stories of great lamas frequently making trips to Tibet in the form of snow leopards, in search of rare medicinal herbs. Other folklore are animal and ecological friendly that describes the snow leopard as a fence for the crops, meaning that in the absence of snow leopards livestock would be free ranging and thus would invade crop fields. Local inhabitants still believe that snow leopards (and domestic cats) are considered to have taken birth particularly to remove the sins of their past lives, and killing these animals' means having their sins transferred to our own life. In Mustang, killing a snow leopard is considered to be more aberrant than its prey species (e.g. blue sheep), because all sins it has committed during its lifetime by killing its prey will then be transferred to us.

In nutshell, Nepali folk tales are from rural and urban communities and regions that shows the identities of different groupsHindus, Non-Hindus, Aryan, Mongolian. They express various aspects of country life, offer an insight into the complexities of the human mind and provide a panoramic view of the cultural, ecology and social life of Nepaliethnic folk. Also reflected in them are many local lifestyles, activities, beliefs, feelings, superstitions, customs and inhibitions, as well as a deep faith in the bizarre. Nepali folklore depicts the relationship of local people with their culture (ethno-cognitive perspective) and persisting scenario of folk traditions, explaining the natives view on local tales who 
possess a unique system of perceiving and organizing phenomenon and their ecology. They make a micro review of cultures, gestures, objects and language (Culture and Symbolic perspective), which form the basis of human communication and myths as well as oral traditions of folktales. Nepali folklore is means of communication of language, a form of ritual expression, cultural interpretation, expression of art and belief constructed on the basis of different meanings and symbols. There are different meanings of symbols hence there are diverse Nepali folklore that differs according to religion, region and anthropological perspectives helps to comprehend this. However, there is the dearth of adequate anthropological researches on different Nepali folklores across different cultures, regions and caste/ethnicities. For example, various folklores from Terai region of Nepal are on the verge of disappearance hence demanding for adequate attention before it is too late. Hence this study recommends and suggests for innovative anthropological research studies on Terai folklores.

\section{CONCLUSIONS}

Folklore is for interaction in an established culture, managing social/cultural situations in various institutional settings and for identity making. These also contribute for giving stability and solidarity, keeping intact and unite the culture and community. Nepali folks did identify themselves as Nepali, not merely any ethnicities, and that the folk did have greater political insight than what is generally acknowledged. This anthropological framing is grounded in systems of meanings and relationships that mediate human engagements with myths and processes related to folklore and the change in cultures, traditions, politics, ethics, ecological degradation and the rising consumerism and globalization. Anthropology's potential contributions to folklore and myths researches are the description and analysis of the mediating layers of cultural meanings, norms and social practices, which cannot be easily incarcerate by methods of other disciplines. There are vital key contributions that anthropology can bring to the understandings of the folklore. The foremost is the awareness to the cultural values and social-cultural, political and ecological relations that shape the production and interpretation of folklore traditions and shape the basis of responses to changes as cultural changes. Anthropological knowledge is holistic referring to the study of the whole of the human condition: past, present, and future; biology, society, language, and culture. Folklore is ultimately about culture, for in its wake, more and more of the intimate humanculture relations, fundamental to the world's cultural diversity. Anthropological lens cram to learn about human significance of folklore by studying the manner and the knowledge system of people in different cultures and communities to understand to the new contexts of folklore, 
new technologies and the local responses to understand and grasp it. Through anthropological lenses on the scale of local levels, anthropologists perceive the vitality and effects of folklore to be about people and their life, survival, ecology, power and politics, ethics and morals, costs and justice, and cultural and spiritual endurance. However, perceiving the challenge that cultural changes poses and crafting appropriate mechanisms, requires input from the breadth of anthropology. Anthropology's in-depth fieldwork methodology, long engagement in questions of society-cultural interactions and broad, holistic view of society yields valuable insights into folklore and cultural change. Yet the discipline's voice in folklore debates has remained a relatively marginal one until now. However, anthropological knowledge/lens enriches and deepens contemporary understandings of folklore. From discussions allied to definitions of folklore to its association to anthropology and the folklore research methods in anthropology it is construed that folklore are being impacted from factors like cultural, community and societal activities, changes, media, technology etc. Anthropological lens seek to respond to folklore at the local, regional, national, and global scales and are helpful in reflecting the understandings in application and seeking ways to pool resources with communities to assist them in preserving folklore or in bridging the science-community dissection---understanding and analyzing ethnic behaviors, their identity and institutions, micro-macro structural relations, and resolving the discrepancy between agency and structure.

\section{ACKNOWLEDGEMENTS}

I am grateful to all those who helped me directly or indirectly in preparing this research article. Very special thanks to my family members for their encouragement. I would like to thank all my friends for their valuable suggestions. My gratitude also goes to members of the Central Department of Sociology/Anthropology, Kirtipur, and Department of Sociology/ Anthropology, Prithvi Narayan Campus, Pokhara for their productive suggestions. I thank the Office of the Rector, T.U. for acknowledging my article for publication in T.U. Journal Vol. No. XXIX, NO.1.

\section{WORKS CITED}

Anderson, E.N. (2003). "Four-Field Anthropology." Anthropology News. DOI, Volume 44, Issue 5, pp. 41-44.

Alice Beck Kehoe (1998). "Humans: An Introduction to Four-Field Anthropology." Psychology Press, Social Science, p. 17.

Ben-Amos, Dan (1973). "A History of Folklore Studies: Why Do We Need It?"Journal of the Folklore Institute. 10:113-124.

Borofsky, R. (2002). "The Four Subfields: Anthropologists as Mythmakers." American Anthropologist. 104: 34-39. 
Fisher, William T. (1989). "Retold Tales: Towards an Understanding of Spirit Possession in Central Nepal Himalaya." The Journal of the Association of Nepal and Himalayan Studies. Vol. 9:26.

Hicks, Dan. (2013). "Four Field Anthropology: Charter Myths and Time Warps from St. Louis to Oxford." Current Anthropology. 54:20-23.

Malinowski, B. (1923). "The Problem of Meaning in Primitive Languages." In C.K. Ogden and I. A. Richards (ed.). The Meaning of Meaning: A Study of the Influence of Language upon Thought and of the Science of Symbolism. London: Trubner and Co. 32-35.

Maria, G., et al. (2012). "Folklore Research and Its New Challenges: From the Ethnography to Netography."Mediterranean Journal of Social Sciences. 111. 